Int. J. Dev. Biol. 63: 83-92 (2019)

https://doi.org/10.1387/ijdb.180364mj

\title{
A short history of in vitro fertilization (IVF)
}

\author{
MARTIN H. JOHNSON* \\ Anatomy School, Department of Physiology, Development and Neuroscience, Cambridge, UK
}

\begin{abstract}
The history of in vitro fertilization (IVF) in humans from the early attempts in the USA through to the first definitive achievement of IVF by Edwards, Steptoe and Purdy (1969-1978), and the brief period of innovative IVF achievements to Melbourne, Australia, cut short by the passage of restrictive legislation (1979-1984) is recorded. A summary of the key achievements since the mid 1980 s is then given. The shameful connotations of engaging in IVF of those early days is contrasted with its wide acceptance today, in which IVF is setting the norms for modern families.
\end{abstract}

KEY WORDS: IVF, history, Edwards, Steptoe, Purdy

\section{Introduction}

The history of mammalian IVF begins in 1930s USA, when Pincus famously, but controversially, claimed to have produced rabbit off-spring after fertilizing rabbit eggs in vitro (Pincus and Enzmann, 1934). Later, Rock and his research collaborator Miriam Menkin experimented on both fertilized and unfertilized eggs retrieved from patients during surgery, and in 1944 claimed the fertilization and cleavage in vitro of three human ova (Rock and Menkin, 1944). Then in 1951 Chang (1951) and Austin (1951) independently discovered capacitation, the requirement for sperm to undergo a series of surface changes in the uterus before they are capable of fertilizing the egg. This discovery led Austin (1961) to reevaluate the previous claims to have successfully fertilized eggs in vitro, producing five criteria which had not til that stage been satisfied in humans: namely that, (1) capacitated sperm be used, (2) use of aged ova be avoided, (3) there be clear evidence that sperm had entered the ooplasm, (4) the possibility of parthenogenetic activation be excluded, and, ultimately, (5) the birth of young genetically identified as related to the transferred embryo(s) be forthcoming. Chang (1959), building on earlier work by Thibault et al., (Douzier and Thibault, 1959) and Moricard (1950), first provided definitive proof of the success of IVF in mammals, by removing unfertilised ripe ova from a rabbit, fertilising them with capacitated sperm, incubating them, and transferring the resultant embryos to another rabbit, which gave birth to viable offspring. This demonstration was followed after 4 years by the successful fertilization of the hamster egg, but not its onward culture beyond the 2-cell stage (Yanagimachi and Chang, 1963, 1964). It was not until 1968 that the mouse egg was successfully fertilized in vitro, cultured to the 2-cell stage, at which time the 2-cells were transferred to the oviducts of recipient mice and in some cases went on to produce viable male and female 17.5 day fetuses that were genetically distinct from the host mother (Whittingham, 1968). During the 1950s and 60s, a small number of scientists continued to pursue the elusive and controversial goal of IVF in humans (e.g. Petrov, 1958; Petrucci, 1961; Hayashi, 1963; Yang, 1963). Among these was Landrum Shettles, a gynaecologist at Columbia University who claimed to replicate the techniques of Rock and Menkin in a series of experiments with retrieved human eggs, but convincing evidence of his success was never published (Shettles, 1955). In 1973, Shettles agreed to attempt IVF and embryo transfer (ET) for a Florida couple John and Doris Del Zio. His experiment was discovered by colleagues and terminated, leading to a lengthy court case and much negative publicity (Hennig, 2003).

\section{Edwards' early work on egg maturation}

It was in this heated context of public debate over IVF and ET, and their potential application to humans, that in 1968 the Cambridge-based reproductive biologist RobertEdwards (Gardner, 2015) established a collaboration with the gynaecologist Patrick Steptoe (Edwards, 1996), who was a consultant in Oldham, Lancashire, and with Cambridge-based nurse-technician Jean Purdy (Johnson and Elder, 2015b). Edwards had previously worked on egg maturation with the underlying motivation to understand the origins of, and if possible to avoid, chromosomal anomalies such as Turner, Klinefelter or Down syndromes, which were first characterized chromosomally in 1959 (Ford et al., 1959; Lejeune

Abbreviations used in this paper: ET, embryo transfer; HCG, human chorionic gonadotrophin; IVF, in vitro fertilization; PGT, preimplantation genetic testing.

*Address correspondence to: Martin H. Johnson. Anatomy School, Department of Physiology, Development and Neuroscience, Downing Street, Cambridge CB2 3DY, UK. Tel: +44 (O) 1223 333777. Fax: +44 (O) 1223 333786. E-mail: Mhj21@ cam.ac.uk - web: https://www.pdn.cam.ac.uk/directory/martin-johnson

(D) https://orcid.org/0000-0002-5906-5883

Submitted: 25 October, 2018; Accepted: 26 November, 2018.

ISSN: Online 1696-3547, Print 0214-6282

(C) 2019 UPV/EHU Press

Printed in Spain 


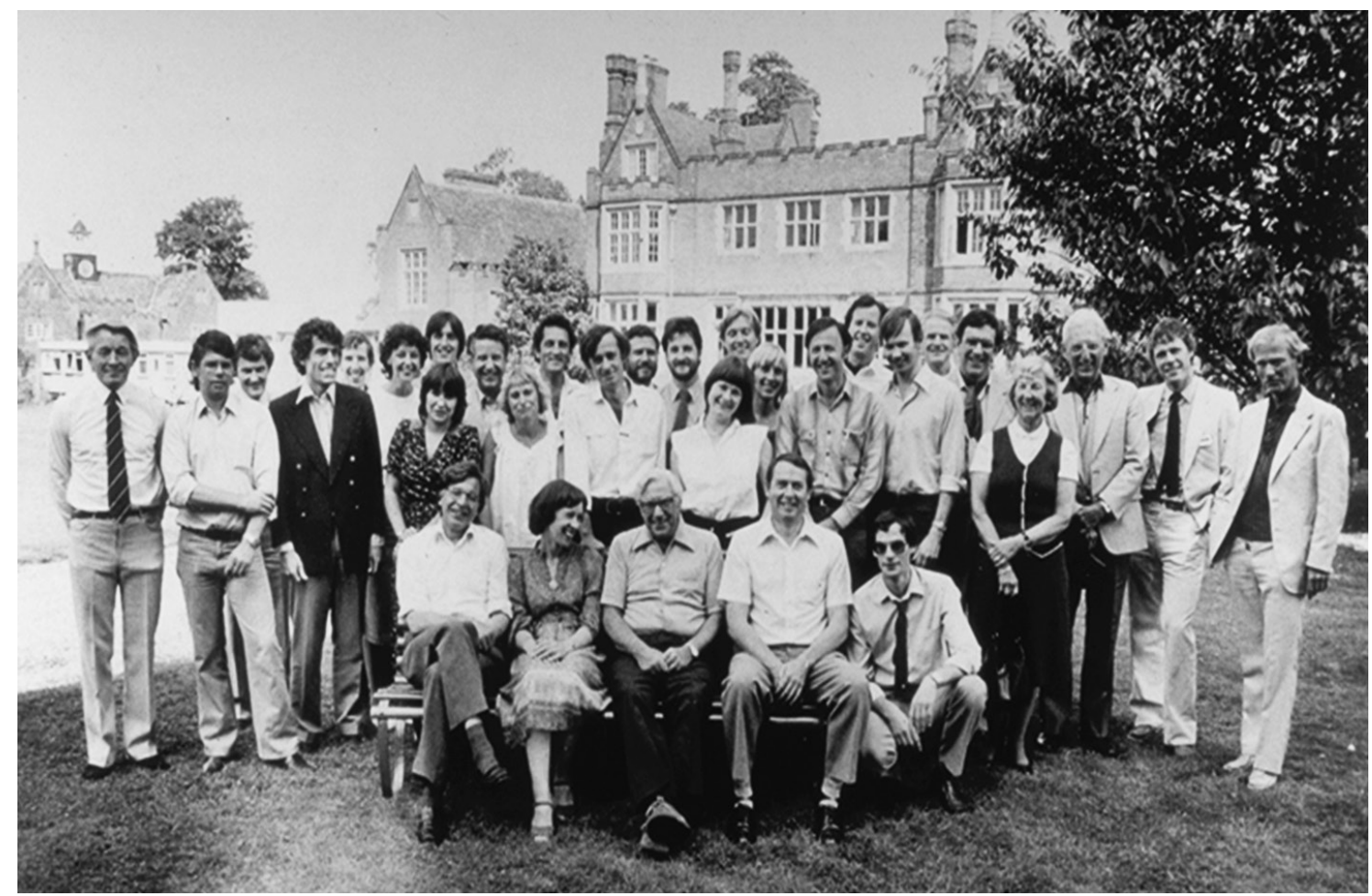

Fig. 1. The First in vitro fertilization (IVF) Meeting in the World, held at Bourn Hall (Cambridgeshire, England) on 3-5th September 1981. The photo was taken by Lennart Nilsson in front of Bourn Hall; Robert G. Edwards (1925-2013), Jean M. Purdy (1945-1985) and Patrick C. Steptoe (1913-1988) are seated on the bench (from the left). A book of the proceedings was published which was edited by Bob Edwards and Jean Purdy (and includes this photo, which is courtesy of the Bourn Hall Clinic.

et al., 1959; Jacobs and Strong, 1959). Thus Edwards, working in the 1950s in Edinburgh, had studied the chromosomal dance that the meiotic mouse egg displayed between receiving the endocrine signal to ovulate and ovulation (Edwards and Gates, 1959). He was able to time this process precisely because, working with his wife Ruth Fowler (Fowler and Edwards, 1957), he had shown that it was possible to stimulate egg maturation in vivo by the appropriate hormonal administration to adult female mice foreshadowing induced ovulation in women a few years later (Gemzell, 1962). After he left Edinburgh to work at the NIMR Mill Hill from 1958, he rediscovered the earlier findings of Pincus and Chang (Pincus and Saunders, 1939; Chang, 1955) that simply releasing the mouse egg from its follicle triggered the same meiotic maturation programme, suggesting that the follicle exercised a restraining influence on the egg, now known to be exerted by cAMP. This observation meant that, were the human egg to show the same spontaneous maturation on release from its follicle, then the opportunity to study this otherwise inaccessible process was a possibility. So Edwards spent the next 6 or so years trying to get eggs of various species, including the human, after their release from ovarian biopsies, to mature in vitro. It took a long time in part because no one then knew how long the interval was in the human between the rise in the level of the luteinising hormone (LH) inducing the initiation of ovulation and the reentry of the egg into meiosis through to second metaphase. It in fact takes considerably longer, around 36 hours in women, than was known for the more studied animals such as the rat or mouse in which it is only 12 hours, and had been reported erroneously by Pincus (Pincus and Saunders, 1939) to be of the same order in the human. However, in 1965 Edwards, who had relocated to the Physiology Department in Cambridge in 1963, was able to publish two papers (Edwards, 1965a,b) describing the detailed time courses of the meiotic maturation of eggs in the mouse, cow, pig, sheep, rhesus monkey and the human. Indeed the paper in the Lancet (Edwards, 1965b) in which he describes the human results, he sets out the potential possibilities and difficulties that flowed from his work with astonishing foresight and imagination.

The discussion in this paper also clearly identifies his then primary interest as not being the alleviation of infertility but the ability to study and thereby to avoid genetic disease (Johnson, 2011). Indeed, within 2-3 years he had demonstrated proof of principle of preimplantation genetic testing (PGT) for disease in the rabbit embryo, over 20 years before PGT was achieved in the human (Gardner and Edwards, 1968). Likewise, working with Cambridge geneticist Alan Henderson, Edwards was to develop his 'production line theory' of egg production to explain the origins of increased levels of maternal aneuploidy in older women. Thus, the earliest mouse eggs to enter meiosis in the fetal ovary were shown to have more chiasmata (thereby being more stable) and to be ovulated earlier in adult life than the those entering meiosis later in fetal life (Edwards, 1970; Henderson and Edwards, 1968).

\section{The consequences of meeting with Steptoe}

It was only after meeting Patrick Steptoe in 1968 that Edwards was persuaded by him that IVF was a means of treating infertility for many couples (Johnson, 2011). This was unsurprising at that time, as in the 1960s, little was known in the UK about the incidence, causes and treatments of infertility (RCOG, 1967; MRC, 
1969; Benninghaus, 2017; Davis, 2017), reproductive sciences focusing on the perceived problem of over-population (Connelly, 2008; Marks, 2001, p. 31, pp. 195-236). This scientific focus, whose practitioners included Edwards, who was then spending most of his time trying to induce immunity to spermatozoa as a potential form of contraceptive (Johnson, 2011), contrasted with that of Steptoe, who had a long term interest in treating the infertile. One of the main reasons that he had developed and pioneered use of laparoscopic surgery in the UK (Steptoe, 1967) was because he then could use the technique to see into the abdomen relatively non-invasively and thereby assess the likely cause of, and prognosis for, infertility in women. When Edwards first entered into a partnership with Steptoe, it was with the idea that Steptoe could help him to overcome the problem of sperm capacitation, with which Edwards had been struggling for 4 years (Edwards et al., 1966, 1968; Johnson, 2011). Thus spermatozoa taken directly from the male ejaculate cannot fertilize the egg unless, as it was believed at that time, they have been capacitated by a period of exposure to the female genital tract fluids (Austin, 1951; Chang, 1951). Edwards had read a publication by Steptoe in which he claimed that he could recover sperm laparoscopically from the oviduct! So hey presto if he could do that, then the recovered spermatozoa could be used to fertilize eggs that Edwards had matured in vitro. However, the first fruits of their collaboration did not involve such sperm recovery, because Barry Bavister working in the Cambridge laboratory on hamster sperm capacitation, had found that sperm could achieve full fertilization capacity without going near the female tract by simply being exposed to raised $\mathrm{pH}$ (Bavister, 1969), and Edwards found the same applied to human spermatozoa! So though Steptoe's name appeared on the 1969 Nature paper, describing the first generally accepted account of successfully in-vitro fertilized human eggs (Edwards et al., 1969), notwithstanding various disputed prior claims (Rock and Menkin, 1944; Shettles, 1955, pp. 505-510; Petrov, 1958; Petrucci, 1961; Hayashi, 1963; Yang, 1963), Steptoe had not supplied many (or possibly any) of the eggs and neither had he supplied the capacitated spermatozoa (Johnson, 2011).

However, at that time, data were emerging that suggested that the maturation of eggs in vitro might allow the chromosomal dance to proceed, but did not result in ooplasmic maturation sufficient to support development. So the attention of Edwards, Steptoe and Purdy (Fig. 1) turned to the development of laparoscopic recovery

\section{TABLE 1}

\section{SOME OF THE MEDICO-SCIENTIFIC CHALLENGES THAT HAD TO BE OVERCOME BEFORE THE FIRST SUCCESSFUL LIVE BIRTH FOLLOWING IVF AND EMBRYO TRANSFER WAS ACHIEVED}

\footnotetext{
Challenges

Technical aspects of follicle aspiration ('new suction gadget'- see Fig. 2)

Ovulation induction

Timing of laparoscopy

Ovarian stimulation

Cycle monitoring

Oocyte culture

Sperm preparation and capacitation

Insemination procedure: medium, timing

Culture for embryo cleavage: medium, assessment

Technical aspects of embryo transfer, including route of transfer, medium and timing

Luteal support
}
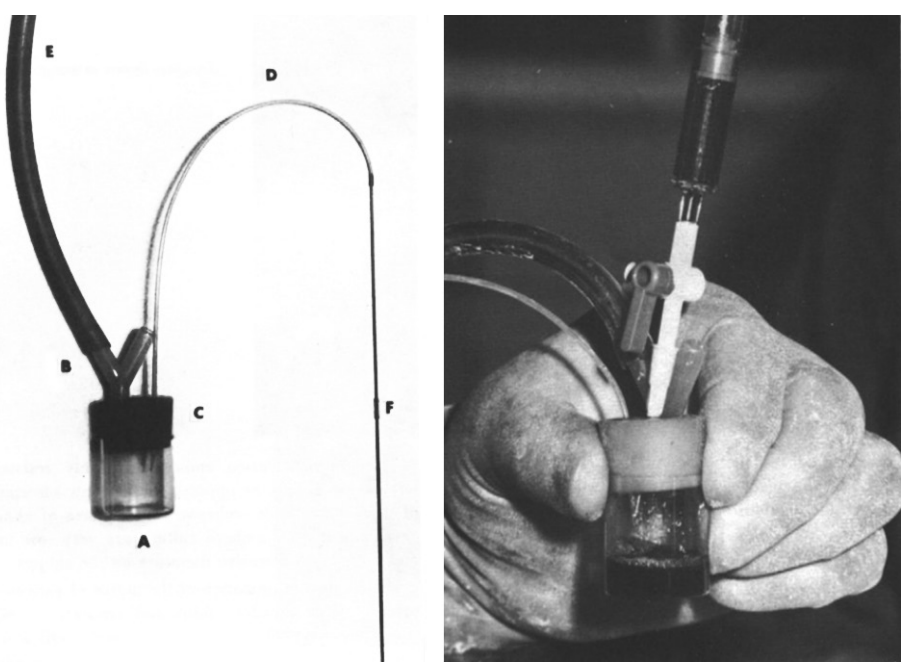

Fig. 2. The "suction device" invented by Edwards and Steptoe (1975) -a simple aspirator for withdrawing the contents of human follicles. A vacuum applied at the wide arm $(\mathbf{E})$ is directed through the needle $(\mathbf{F})$ when required by simply blocking the open Y-arm (B) in the aspirator. Oocyte and follicular fluid are withdrawn through the needle and its lead (D) into the collecting pot (A), which can easily be removed from the neoprene bung (C) and replaced.

of almost matured eggs from the follicles, thereby avoiding this problem. Table 1 indicates the range of then unsolved technical problems that confronted the three pioneers in their quest to produce a baby in this way. Undeterred, Edwards allied his extensive knowledge of the timing of oocyte maturation in vivo with the key technical innovation made by Steptoe - namely surgical use of the laparoscope. Use of this instrument enabled the collection of multiple oocytes, induced by injection of gonadotrophins (Gemzell, 1962), from the intact ovaries of patients under anaesthesia (Steptoe and Edwards, 1970). The laparoscopic approach (or key hole surgery) enabled superior visualization of the inner abdomen by using cold light conducted through a flexible fibre optic tube. The surface of the ovary could thus be clearly observed and the follicles containing eggs punctured with a thin hollow needle passing through the abdominal wall to enable egg collection by suction of the follicle contents - known as aspiration. Preliminary attempts at laparoscopic oocyte recovery (LOR) may have already commenced late in 1968, as reported in Edwards et al., (1969, p.635; published on 15 February, submitted December, 1968). During 1969 the main emphasis was on improving the timing and technique of laparoscopy and recovery of eggs after triggering oocyte maturation. Follicles were initially aspirated using a syringe and needle, but in September 1969 a "new suction gadget "was introduced (Fig. 2), which had a bypass valve that allowed the assistant to control suction, resulting in the collection of clearer follicular fluids. Having tested this suction device with a range of suction pressures, an 'optimum' pressure of no greater than 12 $\mathrm{cm} \mathrm{Hg}$ was settled on, 'since higher pressures may damage the oocytes' (Elder and Johnson, 2015b).

Determining the optimal timing of laparoscopic egg collection was a challenging but crucial component of successful IVF. However, this phase of the research was accomplished fairly rapidly. Thus, the two important initial goals were to aspirate oocytes from their follicles just before ovulation was expected, and to have more 
than one pre-ovulatory oocyte available for aspiration. Injection of the gonadotrophic hormones, human menopausal gonadotrophin (HMG) to stimulate follicle growth, followed by human chorionic gonadotrophin (HCG) to induce terminal follicular maturation, was felt to be necessary in order to control the menstrual cycle and regulate follicle growth, oocyte maturation and ovulation. HCG was administered when an adequate concentration of urinary oestrogens was detected in 24-hour samples (>75 $\mu \mathrm{g} /$ day), but given to allow laparoscopic recovery at a suitable time (usually early in the morning or later at night as the staff were volunteers working outside their normal hours; Johnson and Elder, 2015c). By September 1969 onwards, "a regimen of three injections of HMG between days 2 and 9, and 5000 IU of HCG on days 9-11 of the menstrual cycle was adopted as giving the best response" (Steptoe and Edwards, 1970). The interval between HCG and egg collection was also varied, and the duration of this interval was compared with the presence of corpora lutea to confirm whether or not ovulation had already taken place at the time of laparoscopy. At first, laparoscopy was carried out on days 10-12, with an initial interval between HCG and laparoscopy of 28.75-29.50 h, increased to 29.50-30.00 h from mid-January 1970, and then to 32.0-33.5 h in mid-March 1970 (Elder and Johnson, 2015b). Most eggs recovered during 1969, when the average yield per follicle was only $33 \%$, were examined for their normality cytologically or chromosomally, but many were found to be immature. This finding led them to culture the recovered eggs in drops of their own follicular fluid (wherever was possible) for 1-4 hours before they were inseminated in vitro with in vitro capacitated sperm in a modifed medium developed for his hamster fertilization studies by Barry Bavister initially, although later moving to an Earle's based medium, both at $\mathrm{pH} 7.55$. From 1970 approximately $50 \%$ of follicles yielded eggs, and the first attempted fertilization of eggs is described as being on 23 October and 21 to 24 November 1969 (Elder and Johnson, 2015a). Between 1969 and 1971, Edwards, Steptoe and Purdy successfully achieved cleavage and blastocyst formation in vitro (Edwards et al., 1970; Steptoe et al., 1971), and in December 1971 commenced transfer of embryos (mostly at the 8-16 cell stage) to women to try and achieve pregnancy (Elder and Johnson, 2015a).

\section{The problem of implantation}

Despite the long history of scientific and technological innovation preceding them, and their own innovations, Edwards, Steptoe and Purdy struggled to achieve successful implantation, and it was almost a decade from the first successful fertilization of a human egg in vitro in 1969 to the birth of Louise Brown in 1978 (Edwards and Steptoe, 1978). The problems were twofold: (1) they did not know whether the embryos that they were putting back had the potential to develop further, and (2) they were unsure whether the right hormonal conditions for implantation were vitiated by the hormonal stimulation required to induce multiple follicles to mature. With regard to the first uncertainty, they had considerable experience with animal embryo culture by which to be encouraged. Thus, by the 1950s it had been established that the culture of mouse embryos from the 8-cell stage to the blastocyst required glucose (Hammond, 1949; Whitten, 1956) and that their transfer to recipient uteri could result in live young (McLaren and Biggers, 1958). By the early 1970s it had become clear that mouse 2-cell embryos recovered from the female tract could also be cultured successfully in vitro to blastocyst stages and then transferred to the uterus with the production of live young (Cholewa and Whitten, 1970) and that some mouse embryos could even be cultured to the blastocyst stage from the pronuclear stage and live young result (Whitten and Biggers, 1968). Moreover, it had also been established that culture from the 2-cell stage to the 8-cell stage required lactate or pyruvate (Whitten, 1957; Brinster, 1965a,b). Brinster (1963) had also introduced a revolutionary method for culturing mouse embryos in small drops of medium under paraffin oil rather than in the larger volume test tubes, as had been done previously, an approach adopted by Edwards from January 1970 (Elder and Johnson, 2015b). Notwithstanding these advances in culture conditions and media, which Edwards could build on, it was also clear that most embryos of most species examined blocked during in vitro culture from the 1-cell stage at a stage characteristic for the species, which later turned out to coincide with the speciesspecific time of major activation of the embryo's genes. This had limited the successful use of IVF in animals. In addition, it had also been found that the premature transfer of animal embryos to uteri at a stage earlier than the embryos would be transported there naturally, resulted in the death of the embryos. If either of these situations had applied to the human, it would have made the task of Edwards harder. Fortunately, no evidence of a block to development was found to occur in the human, and Marston et al., (Marston et al., 1977), found that the requirement for synchrony was not as rigorous in the primate as in the rodent. In fact, Edwards, aside from adopting a modified version of Bavister's medium for the fertilization phase, chose to largely ignore the work on mouse embryo culture in his choice of media, using more complex media involving bovine or serum albumen, or fetal calf serum, or the patient's follicular fluid or serum. Thus, by the end of 1970, he was using variants of a Tyrode's B based medium for sperm and egg washing and fertilization, and a Ham's F10 and F12 based medium for cleavage culture (Elder and Johnson, 2015b), both with the accompanying macromolecular fluids. However, their success in culturing embryos to the blastocyst stage caused the team to turn their attention to the luteal phase endocrine conditions on which they then focussed.

This problem was less tractable (Elder and Johnson, 2015a,b). Thus, despite transferring embryos from 1972 onwards, they only got the first evidence of a clinical pregnancy in 1975, but this turned out to be ectopic, a biochemical pregnancy (detected via a transient rise in HCG blood levels) occurring the following year (Elder and Johnson, 2015a). Edwards was aware that high levels of oestrogen in the follicular phase, induced by the higher repeated doses of HMG being used, were unfavourable for the luteal phase endometrium and indeed shortened the luteal phase, and so attempts were made at the beginning of 1973 to reduce the high oestrogen levels by replacing for some patients HMG stimulation with clomiphene-stimulated cycles + HCG to induce follicular maturation. However, these cycles resulted in very low egg recovery rates and so were abandoned (Elder and Johnson, 2015b), and the use of HMG restored from 1975 to 1977. Provision of exogenous luteal support was attempted by luteal administration of Pregnyl, first tried in October 1972, or of both Pregnyl and intramuscular progesterone, during 1973-74, with the addition of Primolut depot (hydroxyprogesterone hexanoate) in July 1975, along with occasional use of Ritodrine, Indocid, and Ethinyl Estradiol 
supplementation. With the finding that prolactin was elevated in many patients, daily bromocryptine was added from the mid-follicular phase and throughout the luteal phase between February and July 1977. However, these attempts were without success, and the decision was taken towards the end of 1977, to avoid the use of exogenous hormones altogether and thereby the accompanying adverse effects on oestrogen levels and the luteal phase. This introduction of natural cycles in parallel with more detailed endocrine monitoring meant a reduction in the numbers of eggs recovered, but with better overall success in retrieving competent preovulatory oocytes for successful IVF (Elder and Johnson, 2015b), that led to the birth of Louise Brown. This success, together with the second birth that followed it in 1979 plus two miscarriages (Elder and Johnson, 2015b), were achieved via the collection of the one egg destined to be naturally ovulated each cycle. This procedure involved the regular collection of urine samples every 2-3 hours, in which the rising level of $\mathrm{LH}$ was assayed to guide the time of laparoscopic egg recovery before natural ovulation could occur - a considerable achievement!

In addition to this wide range of clinical and scientific problems, Edwards, Steptoe and Purdy also faced constant ethical objections to their work, to which they responded robustly (e.g. Edwards and Sharpe, 1971; Edwards, 1974), and proceeded under near constant critical scrutiny by both the media and their clinical and scientific colleagues (Johnson et al., 2010; Johnson, 2018).

\section{Enter Australian medico-scientists}

Edwards, Steptoe and Purdy's successes in 1978 and 1979 opened the door to the rapid clinical expansion of IVF and embryo transfer, through which millions of IVF babies have been born worldwide. However, because the three pioneers had to relocate from Oldham on account of Patrick Steptoe having reached retirement age, and because this relocation was not supported by either the NHS or Cambridge University, there was an enforced hiatus in their work until 1982 as they sought private premises and built the necessary infrastructure at Bourn Hall in Cambridgeshire. During this period the initiative passed to Melbourne in Australia, where two groups had been working on IVF since the early 1970s stimulated to do so by Edwards' 1969 demonstration of successful IVF. And it was in Melbourne that the next clutch of IVF births occurred, the first using the natural cycle approach successfully used by Edwards and his colleagues (Lopata et al., 1980). In Melbourne a significant advance was made in the successful use of hormonal control of ovulation by use of clomiphene citrate with or without a dose of HCG in the recovery of eggs for IVF (Trounson et al., 1981; and soon followed by the successful use in the USA of HMG and HCG; Coddington and Oehninger, 2018), the first use of egg donation (Trounson et al., 1983) occurred, and embryo freezing was used successfully to generate a pregnancy for the first time (Trounson and Mohr, 1983). However, this period of Australian dominance was cut short by the introduction in 1984 of ambiguous and restrictive legislation by the state of Victoria that inhibited the inventive environment that had existed hitherto. Thus, IVF was initially a joint enterprise, allegedly stimulated in 1970 through conversations with Edwards (Wood \& Westmore, 1984, p.43) between Carl Wood and John Leeton at Queen Victoria Hospital (QVH) associated with Monash University, and, from 1972 by lan Johnston and James Brown at Royal Womens' Hospital (RWH) associated with
Melbourne University (McCalman, 1998, p.358). These clinicians were joined in 1971 by embryologist, Alex Lopata, when the work got seriously underway. This formidable Australian team reported their first two IVF biochemical pregnancies in 1973 (De Kretser et al., 1973), but neither progressed (Wood \& Westmore, 1984, p.44). In 1977, Alan Trounson joined Wood's team at Monash. Trounson was a graduate of Sydney University (1968-74), who had undertaken post-doctoral training (1974-76) in Cambridge at the ARC Animal Research Station, Huntingdon Road, where he had learnt about egg maturation, fertilization in vitro and embryo transfer and freezing in cows and sheep, and where he had also met Edwards. Then in 1979, the first ongoing pregnancy was reported in a patient at Melbourne RWH, the world's third confirmed test tube baby being born in June, 1980 (Lopata et al., 1980). However, the publicity, which that hospital received upset the Monash team, and led to a split between the two clinics (with Wood and Trounson at Monash, and Johnston and Lopata at Melbourne; Kannegiesser, 1988; Wood and Westmore, 1984, p.46). This split was to have adverse consequences for legislative regulation, as was the almost universal initial hostility of the Australian medical profession and funding bodies (McCalman, 1998, p.361).

However, by early 1982, Australian medical attitudes had softened, and a federal body, the National Health and Medical Research Council (NHMRC, 1982), produced guidance as part of its "Statement on Human Experimentation", which inter alia offered cautious support for research using human embryos as well as the use of IVF for treating infertility (Szoke, 2004, pp. 263, 269-70). This support was followed later by ethical guidance on how to pursue IVF and research on human embryos (NHMRC, 1986). However, these federal interventions stimulated further vociferous public criticism in the catholic dominated state of Victoria. For example, late in 1981, the roman catholic Archbishop of Melbourne sent a telegram to the prime minister of Victoria: "Respectfully request review of [rumoured] grant being used for such callous immoral experiments on human beings" (Waller, 1992, p.19). Partly to deflect these criticisms, and also to provide protection for themselves, Wood requested that QVH establish an ethics committee, which Louis Waller, professor of law at Monash (1965 - 2000), joined in 1981. Wood also asked the State Government to "institute a formal inquiry into the ethics of in vitro fertilisation" (McCalman, 1998, p. 81), which was duly announced in March 1982, and followed on $25^{\text {th }}$ May 1982 with the information that it was to be chaired by Waller (Waller, 1990). Within 3 months it produced an interim report, which stated that the "the procedures were acceptable and their unanimous view was that the appropriate way to regulate the new developments was by legislation"(Szoke, 2004, p. 273). There then followed an ill-advised action by the team at Monash that cast doubt on their responsibility. Thus, Wood, having announced in the Age (news paper) the first use of egg donation to massive public criticism, was requested by the state Premiere and Attorney General to discontinue their work in this area "until the report on the use of donor gametes was finished and the legal issues resolved". However, the team transferred their work in 1982 from a state hospital to the private Epworth Hospital, where it continued, allegedly due to Trounson's furious reaction (Szoke, 2004, p.275-6; Kannegiesser, 1988, p.86). Dismayed by this action, the Victorian Government pressured Waller to a rapid conclusion, which occurred with the introduction of the Infertility (Medical Procedures) Bill in March 1984, before Waller had time to consider the issue 
of research on embryos (Szoke, 2004, p. 288), and also the year that the Warnock committee (set up by the UK government in 1982 to investigate the regulation of IVF in the UK) reported and six years before the HFE Act based on it was passed into law in the UK. A key consequence of this rush to legislate in Victoria, which was completed in 1984, was that there was little opportunity there to engage the public and MPs in an educational process, nor for alliance building to achieve this outcome (Szoke, 2004, p. 307), as occurred in the UK. This deficiency was exacerbated by the fact that the two clinics involved in development of IVF saw each other as competitors and so did not work together effectively to recruit wider support, particularly critical in that women's liberation groups joined forces in opposition in an 'unholy' alliance with the catholic church (Rowland 1984; Klein, 1989), an adverse feminist reaction that was not mollified by the uncompromisingly combative style adopted by the medical teams (Szoke, 2004, p.279-280). The outcome was legislation that included restrictions on treatment to married couples and on embryo research that significantly restricted the scope of research work in Victoria (Szoke, 2004 p. 297). This legislation, combined with political pressure from the State government, led to the movement out-of-State by some of the key players (Leeton, 2013; Wilton, 2018).

\section{Subsequent developments}

Since then there have been changes to the technique of egg aspiration, which is now achieved under local anaesthesia by ultrasound guidance (Lenz and Lauritsen, 1982) via the vaginal vault (Wikland et al., 1985), to embryo culture methods permitting successful culture to the blastocyst stage (Gardner and Lane, 1998), as well as to embryo selection criteria and cryopreservation techniques that have reduced the transfer of multiple embryos and so the problems attendant on multiple births (Racowsky et al., 2010). Freezing of oocytes has been possible since 1996 and has become more common in the past 5 years with the introduction of vitrification (Cobo et al., 2010). Moreover, the introduction in 1992 of Intra-Cytoplasmic Sperm Injection (ICSI; Van Steirteghem et al., 1993) revolutionized treatment of male infertility. Despite the proof of principle for PGT being established in 1968 (Gardner and Edwards, 1968), it was only in 1986 that clinical interest was roused and the pace of research quickened (Theodosiou and Johnson, 2002) such that the first PGT pregnancies were reported in 1990 (Handyside et al., 1990). Moreover, it is only over the past $10-15$ years that PGT has taken off clinically, especially in the United States.

Three technical approaches to PGT biopsy have been applied to four types of clinical application (Wilton, 2018). Post-fertilization, either a trophoblast biopsy from a day 5 blastocyst is used, or, now less commonly used, one or two blastomeres were biopsied from a day 2 or day 3 cleaving embryo. Pre-fertilization sampling of the polar body can be used to identify genetic problems in eggs (Verlinsky et al., 1997), but is no longer commonly used. Each sampling method has advantages and disadvantages in terms of sensitivity and reliability. The sampling technique used can also depend on the purposes for which the diagnostic test is being undertaken, that include: (1) sexing of embryos to avoid transmission of sex-linked genetic disease (Handyside et al., 1990) or, more controversially, and illegally in some jurisdictions, for family balancing. (2) The detection of a growing number of (mostly rare) single-gene defects in the embryo is now possible.
PGT for monogenic disease (PGT-M) offers a way to establish a pregnancy, confident that a disease-free child will be born, thereby avoiding the distress of an affected birth or the consideration of a later termination (Handyside et al., 1992). For early-onset severe or lethal diseases, the use of PGT-M is relatively noncontroversial ethically. However, increasingly PGT-M is being considered for late-onset, variably penetrant, and less severe conditions. It is also possible, but illegal in most jurisdictions, to use PGT to select for certain genes, either for genes conferring an affected phenotype to match a parental condition (e.g., deafness or dwarfism) or to confirm parental choice - so-called 'designer babies'. (3) Chromosomal anomalies, such as errors of somy, ploidy and complex translocations, can be detected by preimplantation genetic testing for aneuploidy (PGT-A; Gianaroli et al., 1997). In some clinics, the use of PGT-A in all women, in older women, or in women who have experienced repeated pregnancy loss is controversially becoming almost routine. However, randomized control trials have not provided unequivocal evidence of its beneficial value for widespread or even for selective use (Verpoest et al., 2018), especially given the uncertainty generated by the finding of extensive mosaicism in many blastocyst biopsies (Gleicher, 2018; Braude, 2018). (4) PGT has also been used to produce so-called 'savior siblings', in which an embryo is typed for histocompatibility with an existing sibling who has a disease requiring a tissue graft - provided by the cord blood cells from the 'savior sibling' (Verlinsky et al., 2001). Each of these applications of PGT raises ethical issues, and the legal response to consideration of these issues has been very varied in different countries.

The technology used for the genetic diagnosis of a biopsied sample is also varied and tailored to the purpose for which the test is being used. Initially, two types of tests were used: (i) fluorescent in situ hybridization (FISH) to detect abnormal karyotypes, structural chromosomal anomalies, or embryo sex (Griffen etal.,1993) and (ii) various types of polymerization chain reaction (PCR) for single-gene detection (Handyside et al., 1990). Recent improvements in whole-genome amplification (WGA) and array technologies are revolutionizing detection methodology. WGA facilitated PCR-based chromosomal testing (Wells et al., 1999), and its use has proved promising in conjunction with two types of array that have been developed: array comparative genomic hybridization (aCGH:LeCaignec etal., 2006) and single-nucleotide polymorphism (SNP)-based arrays. Both array types can be used to determine anomalous chromosome number, but only SNP-based arrays can be used for haplotyping the samples. These techniques are being superceded by use of next generation sequencing (NGS) approaches that provide a more automated and therefore less expensive approach than array CGH. Handyside et al. (2010) have used karyomapping, which involves bioinformatic analysis of SNP array data to allow both single gene errors (PGT-M) in combination with many errors in ploidy to be detected in the same biopsy samples. And soon even biopsy may not be necessary by sampling the DNA released into the culture medium by embryos (Palini et al., 2013). In addition to PGT, modification of the genetic composition of embryos has also been reported. Reproductively in the case of mitochondrial transfer, in order to counteract the presence of faulty mitochondria, by which technique a single child has been born thus far (Zhang et al., 2017), in somewhat controversial circumstances (Alikani et al., 2017), although the HFEA has now licensed this approach under strict conditions for use in the UK. A 
number of laboratories have also used a CRISPR/Cas9-mediated gene editing approach to modify the genetic composition of human eggs for experimental purposes only (Liang et al., 2015; Fogarty et al., 2017; Schenkwein and Yia-Herttuala, 2018), and recently Japan has promised draft guidelines on the use of the technique experimentally that will be open for public comment from November 2018 and are likely to be implemented in the first half of next year (Cyranoksi, 2018). Currently, the use of the technique reproductively is legally banned in the UK, but not in the USA or China, where recent unconfirmed reporfs of its use in humans to produce children are being investigated.

IVF has also permitted the production of human embryonic stem cells (ESCs) in 1998 (Thomson et al., 1998), following their successful derivation in rabbits by Edwards, with Robin Cole and John Paul (Cole et al., 1966) and in mice by Evans and Kaufman (1981) and Martin (1981). In combination with somatic cell nuclear transfer (SCNT, first described successfully for sheep in 1996; Campbell et al., 1996), the use of ESCs allows the production of pluripotent cell lines matched genetically to the nuclear donor. This approach opens the possibility of tissue repair and cell therapy. However, the use of other sources of pluripotent cell lines, such as induced stem cells (Takahashi and Yamanaka, 2006), may turn out to be ethically more acceptable and practically less demanding.

Recently, human embryos have been cultured in vitro in a matrix that has allowed them to develop for up to 12-13 days, approaching the legally-permitted limit of 14 days in the UK. Surprisingly, the embryos seem to undergo normal morphogenesis, forming a proamniotic cavity in the absence of any maternal input, suggesting that the pattern of early development resides entirely within the embryo itself (Deglincerti et al., 2016). Such in vitro implanted embryos may be able to develop for another 1-2 weeks thereby permitting the study of the generation of the primitive streak and the gametes (germ line) in vitro, subject to a change in the law. Even without a change in the law, the study of in vitro implantation over the period of gastrulation by use of human embryo-like entities may be possible, as recently use of aggregates of mouse ES cells have been found to function in many respects comparably to embryos up to pregastrulation stages in mouse (Bedzhov and Zernicka-Goetz, 2014). When trophoblast stem cells are also added better development is observed (Harrison et al., 2017), and the addition of a third cell line, equivalent to the hypoblast in the mouse, has taken the embryos through a quasi gastrulation with the formation of germ cells (Sozen et al., 2018). For humans, where only ESC lines exist at present (equivalent to epiblast), development of embryo-like structures is becoming possible (Shahbazi and Zernicka-Goetz, 2018) meaning that discovery of hypoblast and trophoblast human stem cell lines is pressing.

Finally, a recent development has promised to bring IVF to the poorer members of society, with the demonstration that the whole procedure can be conducted more simply and thus more cheaply, in the "walking egg project' (van Blerkom et al., 2014) - a development that would have appealed to the egalitarian values of Bob Edwards. This system reproducibly generates de novo the atmospheric and culture conditions that support normal fertilization and preimplantation embryogenesis to the hatched blastocyst stage without the need for specialized medical-grade gases or equipment. Development from insemination to the hatched blastocyst stage occurs undisturbed in a completely closed system that enables timed performance assessments for embryo selection in situ that, in this study, involved single-embryo transfers on day 3 . With the simplified culture system, 8 of 23 embryos that were transferred implanted, one miscarried at 8 weeks of gestation and seven healthy babies were born.

\section{Conclusions}

From its early contested beginnings, IVF now offers a range of technical possibilities that theoretically allow us to control the reproductive process in many ways. This modern technology is also changing the meaning of families; thus dead mothers and fathers can still produce genetic offspring, two mothers or two fathers can parent a child, indeed the meaning of the terms father and mother has changed and multiplied. IVF has also become so normalized compared with the early days, when its use was considered shameful, that now it sets the standard for natural methods of reproduction (Franklin, 2013). Truly, Edwards, Steptoe and Purdy started a scientific and social revolution with their pioneering discovery of IVF, for which in 2010 Edwards was awarded the Nobel Prize for Physiology and Medicine 'for the development of in vitro fertilization' (Nobel, 2010).

\section{Acknowledgements}

The authorgratefully acknowledges support from the Wellcome Trust via grants 088708 to Nick Hopwood, Martin Johnson et al., 100606 to Sarah Franklin, and 094985 to Allen Packwood and Martin Johnson.

\section{References}

ALIKANI M, FAUSER B C J, GARCIA-VALESCO J A, SIMPSON J L, JOHNSON M H (2017). First birth following spindle transfer for mitochondrial replacement therapy: hope and trepidation. Reprod BioMed Online 34: 333-336.

AUSTIN C R (1951). Observations of the penetration of sperm into the mammalian egg. Austral. J Sci Res Series B 4: 581-596.

AUSTINCR(1961). Fertilization of mammalian eggs in vitro. Int Rev Cyto/12: 337-359.

BAVISTER B D (1969). Environmental factors important for in vitro fertilization in the hamster. Reprod 18: 544-545.

BEDZHOV I, ZERNICKA-GOETZ M (2014). Self-organizing properties of mouse pluripotent cells initiate morphogenesis upon implantation. Cell 156: 1032-1044.

BENNINGHAUS C (2017). Silences: coping with infertility in 19th century Germany. In The Parrrave handbook of infertility (Eds. G. Davis and T. Loughran). Palgrave Macmillan, London, pp. 99-132.

BRAUDEPR (2018). The emperor still looks naked. Reprod BioMed Online37: 133-135.

BRINSTER R L (1963). A method for in vitro cultivation of mouse ova from two-cell to blastocyst. Exp Cell Res 32: 205-208.

BRINSTER R L (1965a). Studies on the development of mouse embryos in vitro. II. The effect of energy source. J Exp Zool 158: 59-68.

BRINSTER R L (1965b). Studies on the development of mouse embryos in vitro. III. The effect of fixed-nitrogen source. J Exp Zool 158: 69-77.

CAMPBELL K H, MCWHIR J, RITCHIE W A, WILMUT I (1996). Sheep cloned by nuclear transfer from a cultured cell line. Nature 380: 64-66.

CHANG M C (1951). Fertilizing capacity of spermatozoa deposited into the fallopian tubes. Nature 168: 697-698.

CHANG M C (1959). Fertilization of rabbit ova in vitro. Nature 184, 466-467.

COBO A, MESAGUER M, REMOHI J, PELLICER A (2010). Use of cryo-banked oocytes in an ovum donation programme: a prospective, randomised, controlled clinical trial. Hum Reprod 25: 2239-2246.

CODDINGTON C C III, OEHNINGERSC (2018). The Joneses and the Jones Institute. In In-Vitro Fertilization; The Pioneers History (Eds G Kovacs, P Brinsden, and A deCherney). CUP, Cambridge. pp. 66-74.

COLE R J, EDWARDS R G, PAUL J (1966). Cytodifferentiation and embryogenesis in cell colonies and tissue cultures derived from ova and blastocysts of the rabbit. 
Dev Biol 13: 385-407.

CONNELLYM (2008). Fatal Misconception: The Struggle to Control World Population. Harvard University Press, Cambridge, USA.

CYRANOSKI D (2018). Japan set to allow gene editing in human embryos. Nature doi: 10.1038/d41586-018-06847-7

DAUZIER L, THIBAULT C. (1959). New data on the in vitro fertilization of rabbit and ewe ova. C R Hedb Sceanc Acad Sci 248: 2655-2656.

DAVIS G (2017). Oral history and women's accounts of infertility in postwar Britain. In The Parrrave handbook of infertility (Eds G. Davis and T. Loughran). Palgrave Macmillan, London. pp.123-140.

DE KRETSER D, DENNIS P, HUDSON B, LEETON J, LOPATA A, OUTCH K, TALBOT J, WOOD C (1973). Transfer of a human zygote. Lancet 7831: 728-729.

DEGLINCERTI A, CROFT G F, PIETILA L N, ZERNICKA-GOETZ M, SIGGIA E D, BRIVANLOU AH (2016). Self-organization of the in vitro attached human embryo. Nature 533: 251-254.

EDWARDS R G (1974). Fertilization of human eggs in vitro: morals, ethics and the law. $Q$ Rev Biol: 49, 3-26.

EDWARDSR G (1965a). Maturation in vitro of mouse, sheep, cow, pig, rhesus monkey and human ovarian oocytes. Nature: 208, 349-351.

EDWARDS R G (1965b). Maturation in vitro of human ovarian oocytes. Lancet 286: 926-929.

EDWARDS R G (1996). Patrick Christopher Steptoe, C. B. E. 9 June 1913-22 March 1988. Biorr Mems Fell R Soc 42: 435-452.

EDWARDS R G, Gates A H (1959). Timing of the stages of the maturation divisions, ovulation, fertilization and the first cleavage of eggs of adult mice treated with gonadotrophins. J Endocr: 18, 292-304.

EDWARDS R G, SHARPE D J (1971). Social values and research in human embryology. Nature 231: 87-91.

EDWARDS R G, STEPTOE P C (1975). Induction of follicular growth, ovulation and luteinization in the human ovary. J Reprod Fert (Supplement) 22: 121-163.

EDWARDS R G, STEPTOE P C (1978). Birth after the reimplantation of a human embryo. Lancet 312: 366

EDWARDS R G, BAVISTER B D, STEPTOE P C (1969). Early stages of fertilization in vitro of human oocytes matured in vitro. Nature 221: 632-635.

EDWARDS R G, DONAHUE R P, BARAMKI T A,JONES Jr, H W (1966). Preliminary attempts to fertilize human oocytes matured in vitro. Am J Obstet Gynec 96: 192-200.

EDWARDS R G, STEPTOE P C, PURDY J M (1970). Fertilization and cleavage in vitro of preovulatory human oocytes. Nature 227: 1307-1309.

EDWARDS R G, TALBERT L, ISRAELSTAM D, NINO H N, JOHNSON M H (1968). Diffusion chamber for exposing spermatozoa to human uterine secretions. Am J Obstet Gynec 102: 388-396.

ELDER K, JOHNSON M H (2015a). The Oldham Notebooks: an analysis of the development of IVF 1969-1978. II The treatment cycles and their outcomes. Reprod BioMed Soc 1: 9-18.

ELDER K, JOHNSON M H (2015b). The Oldham Notebooks: an analysis of the development of IVF 1969-1978. III. Variations in procedures. Reprod BioMed Soc 1: 19-33

EVANS M J, KAUFMAN M H (1981). Establishment in culture of pluripotential cells from mouse embryos. Nature 292: 154-156.

FOGARTY N M E, MCCARTHY A, SNIJDERS K E, POWELL B E, KUBIKOVA N, BLAKELEY P, LEA R, ELDER K, WAMAITHAS E, KIM D, MACIULYTE V, KLEINJUNG J, KIM J S, WELLS D, VALLIER L, BERTERO A, TURNER J M A, NIAKAN K K (2017). Genome editing reveals a role for OCT4 in human embryogenesis. Nature 550: 67-73.

FORD C E, JONES K W, POLANI P E, DE ALMEIDA J C, BRIGGS J H (1959). A sex-chromosome anomaly in a case of gonadal dysgenesis (Turner's syndrome). Lancet 273: 711-713.

FOWLER R E, EDWARDS R G (1957). Induction of superovulation and pregnancy in mature mice by gonadotrophins. J Endocr 15: 374-384.

FRANKLIN S (2013). Conception through a looking glass: the paradox of IVF. Reprod BioMed Online 27: 747-755.

GARDNER D K, LANE M (1998). Culture of viable human blastocysts in defined sequential serum-free media. Hum Reprod 13, Suppl 3: 148-159.
GARDNER R L (2015). Sir Robert Geoffrey Edwards C.B.E. 27 September 192510 April 2013. Biorr Mems Fell R Soc 61: 81-102.

GARDNER R L, EDWARDS R G (1968). Control of the sex ratio at full term in the rabbit by transferring sexed blastocysts. Nature 218: 346-349.

GEMZELLCA(1962). The induction of ovulation with human pituitary gonadotrophins. Fert Steril 13: 153-168.

GIANAROLI L, MAGLI M C, FERRARETTI A P, FIORENTINO A, GARRISI J, MUNNÉ $S$ (1997). Preimplantation genetic diagnosis increases the implantation rate in human in vitro fertilization by avoiding the transfer of chromosomally abnormal embryos. Fert Steril 68: 1128-1131.

GLEICHER N, KUSHNIR V A, BARAD D H (2018). How PGS/PGT-A laboratories succeeded in losing all credibility. Reprod BioMed Online 37: 242-245.

GRIFFIN D K, WILTON LJ, HANDYSIDE A H, ATKINSON G H, WINSTON R M, DELHANTY J D (1993). Diagnosis of sex in preimplantation embryos by fluorescent in situ hybridisation. Brit. Med. J. 306: 1382.

GRIFFIN D K, WILTON L J, HANDYSIDE A H, WINSTON R M, DELHANTY J D (1992). Dual fluorescent in situ hybridisation for simultaneous detection of $X$ and $Y$ chromosome-specific probes for the sexing of human preimplantation embryonic nuclei. Hum Genet 89: 18-22.

HANDYSIDE A H, KONTOGIANNI E H, HARDY K, WINSTON R M (1990). Pregnancies from biopsied human preimplantation embryos sexed by Y-specific DNA amplification. Nature 344: 768-770

HANDYSIDE A H, LESKO J G, TARIN J J, WINSTON R M, HUGHES M R (1992). Birth of a normal girl after in vitro fertilization and preimplantation diagnostic testing for cystic fibrosis. N Enrl J Med 327: 905-909.

HANDYSIDE A H, HARTON G L, MARIANI B, THORNHILL A R, AFFARA N, SHAW M A, GRIFFIN D K (2010). Karyomapping: a universal method for genome wide analysis of genetic disease based on mapping crossovers between parental haplotypes. J Med Genet 47: 651-658.

HARRISON S E, SOZEN B, CHRISTODOULOU N, KYPRIANOU C, ZERNICKAGOETZ M (2017). Assembly of embryonic and extraembryonic stem cells to mimic embryogenesis in vitro. Science 356: eaal1810.

HAYASHI M (1963). Fertilization in vitro using human ova. In Proceedinrs of the 7th International Planned Parenthood Federation, Sinrapore. Excerpta Medica International Congress Series No. 72, Amsterdam, Netherlands.

HAMMOND J Jr (1949). Recovery and culture of tubal mouse ova. Nature 163: 28. HENDERSON S A, EDWARDS R G (1968). Chiasma frequency and maternal age in mammals. Nature 218: 22-28.

HENIG R M (2003). The lives they lived; second best. New York Times December 28th at https://www.nytimes.com/2003/12/28/magazine/the-lives-they-livedsecond-best.html

JACOBS P A, STRONG J A (1959). A case of human intersexuality having a possible XXY sex-determining mechanism. Nature 183: 302-303.

JOHNSON M H (2011). Robert Edwards: the path to IVF. Reprod. BioMed. Online 23: $245-262$

JOHNSON M H (2018). Professional Hostility Confronting Edwards, Steptoe, and Purdy in their Pioneering Work on In-Vitro Fertilization. In In-Vitro Fertilization The Pioneers History (EDS. G Kovacs, P Brinsden, A deCherney) CUP, Cambridge. pp. 41-49.

JOHNSON M H, ELDER K (2015a). The OldhamNotebooks: an analysis of the development of IVF 1969-1978. IV. Ethical aspects. Reprod BioMed Soc 1: 34-45.

JOHNSON M H, ELDER K (2015b). The Oldham Notebooks: an analysis of the development of IVF 1969-1978. V. The role of Jean Purdy reassessed. Reprod BioMed Soc 1: 46-57.

JOHNSON M H, ELDER K (2015c). The Oldham Notebooks: an analysis of the development of IVF 1969-1978. VI. Sources of support and patterns of expenditure. Reprod BioMed Soc 1: 58-70

JOHNSON M H, FRANKLIN S B, COTTINGHAM M, HOPWOOD N (2010). Why the Medical Research Council refused Robert Edwards and Patrick Steptoe support for research on human conception in 1971. Hum Reprod 25: 2157-2174.

KANNEGIESSER H (1988). Conception in the test tube. The IVF story: howAustralia leads the world. Macmillan, South Melbourne.

KLEIN R D (1989). Infertility. Women speak out about their experiences of reproduc tive medicine. Pandora Press, London. 
LE CAIGNEC C, SPITS C, SERMON K, DE RYCKE M, THIENPONT B, DEBROCK S, STAESSEN C, MOREAU Y, FRYNS J P, VANSTEIRTEGHEM A, LIEBAERS I, VERMEESCH J R (2006). Single-cell chromosomal imbalances detection by array CGH. Nucleic Acids Res 34: e68.

LEETON J (2013). In Fertility Society of Australia; a History [Ed D M Saunders]. Self published privately, pp.21-3.

LEJEUNE J, GAUTIER M, TURPIN R (1959). Etude des chromosomes somatiques de neuf enfants mongoliens. $C$ Rend Hebd Seanc Acad Sci 248: 1721-1722.

LENZ S, LAURITSEN J G (1982). Ultrasonically guided percutaneous aspiration of human follicles under local anesthesia: a new method of collecting oocytes for in vitro fertilization. Fert Steril 38: 673-677.

LIANG P, XU Y, ZHANG X, DING C, HUANG R, ZHANG Z, LV J, XIE X, CHEN Y, LI Y, SUNY, BAIY, SONGYANG Z, MAW, ZHOU C, HUANG J. (2015). CRISPR/Cas9mediated gene editing in human tripronuclear zygotes. Protein Cell 6: 363-372.

MRC (1969). Research in Obstetrics and Gynaecolory: Report to the Secretary of the Council by SectionA1, General Clinical Medicine. UK National Archives, FD 7/912.

MARKS L V (2001). Sexual Chemistry: A History of the Contraceptive Pill. Yale University Press, New Haven, USA.

MARSTON J H, PENN R, SIVELLE P C (1977). Successful autotransfer of tubal eggs in the rhesus monkey (Macaca mulatta). $J$ Reprod Fertil 49: 175-176.

MARTIN G (1981). Isolation of a pluripotent cell line from early mouse embryos cultured in medium conditioned by teratocarcinoma stem cells. Proc Natl Acad Sci USA 78: 7634-7638.

MCCALMAN J (1998). Sex and sufferinr. Women's health and a women's hospital. M.U.P, Melbourne.

MCLAREN A, BIGGERS J D (1958). Successful development and birth of mice cultivated in vitro as early embryos. Nature 182: 877-878.

MORICARD R (1950). Fecundation in vitro of rabbit ovules and level of potential of oxidation-reduction. J Physiol (Paris) 42: 689-690.

MULKAY M (1997). The embryo research debate: science and the politics of reproduction. Cambridge University Press, Cambridge UK.

NHMRC (1982). Statement on human embryo experiments. NHMRC, Canberra.

NHMRC (1986). Ethical ruidelines on assisted reproductive technolory. NHMRC, Canberra.

NOBEL (2010). Available from: http://nobelprize.org/nobel_prizes/medicine/laureates/2010/announcement.html.

PALINI S, GALLUZZI L, DE STEFANI S, BIANCHI M, WELLS D, MAGNANI M, BULLETTI C (2013). Genomic DNA in human blastocoele fluid. Reprod BioMed Online 26: 603-610.

PETROV G N (1958). Fertilization and first stages of cleavage of human egg in vitro. Arkhiv Anatomii Gistolorii i Embriolorii 35: 88-91.

PETRUCCI D (1961). Producing transplantable human tissue in the laboratory. Discovery 22: 278-283.

PINCUS G, ENZMANN E V (1934). Can Mammalian Eggs Undergo Normal Development in Vitro? Proc Natl Acad Sci USA 20: 121-122.

PINCUS G, SAUNDERS B (1939). The comparative behavior of mammalian eggs in vivo and in vitro. VI. The maturation of human ovarian ova. Anatomical Rec. 75: 537-545.

RACOWSKY C, VERNON M, MAYER J, BALL GD, BEHR B, POMEROY K O, WININGER D, GIBBONS W, CONAGHAN J, STERN J E (2010). Standardization of grading embryo morphology. J Assist Reprod Genet 27: 437-439.

RCOG (1967). The Traininr of Obstetricians and Gynaecolorists in Britain, and Matters Related Thereto: The Macafee Report of a Select Committee to the Council of the Royal College of Obstetricians and Gynaecologists. RCOG, London, UK.

ROCK J, MENKIN M (1944). In vitro fertilization and cleavage of human ovarian eggs. Science 100: 105-107.

ROWLAND R (1984). Reproductive technologies: the final solution to the woman question? In Test-Tube Women. What future for motherhood? (Eds R Arditti, R. Duelli Klein, S. Minden). Pandora Press, London.

SCHENKWEIN D, YIA-HERTTUALA S (2018). Gene Editing of Human Embryos with CRISPR/Cas9: Great Promise Coupled with Important Caveats. Molec Therapy 26: 659-660.

SHAHBAZI M N, ZERNICKA-GOETZ M (2018). Deconstructing and reconstructing the mouse and human early embryo. Nat Cell Biol 20: 878-887.
SHETTLES L B (1955). A morula stage of human ovum developed in vitro. Fert Steril 9: 287-289.

SOZEN B, AMADEI G, COX A, WANG R, NA E, CZUKIEWSKA S, CHAPPELL L, VOET T, MICHEL G, JING N, GLOVER D M, ZERNICKA-GOETZ M (2018). Selfassembly of embryonic and two extra-embryonic stem cell types into gastrulating embryo structures. Nat Cell Biol 20: 979-989.

STEPTOE P C (1967). Laparoscopy in Gynaecolory. E and S. Livingstone, Edinburgh, UK.

STEPTOE P C, EDWARDS R G (1970). Laparoscopic recovery of preovulatory human oocytes after priming of ovaries with gonadotrophins. Lancet 295: 683-689.

STEPTOE P C, EDWARDS R G, PURDY J M (1971). Human blastocysts grown in culture. Nature 229: 132-133.

SZOKE H (2004). Social rerulation, reproductive technolory and the public interest. Policy and process in pioneering jurisdictions. Doctoral dissertation, University of Melbourne.

TAKAHASHI K, YAMANAKAS (2006). Induction of pluripotent stem cells from mouse embryonic and adult fibroblast cultures by defined factors. Cell 126: 663-676.

THEODOSIOU AA, JOHNSON M H (2011). The politics of human embryo research and the motivation to achieve PGD. Reprod BioMed Online 22, 457-471.

THOMPSON J A, ITSKOVITZ-ELDOR J, SHAPIRO S S, WAKNITZ M A, SWIERGIEL J J, MARSHALL V S, JONES J M (1998). Embryonic stem cell lines derived from human blastocysts. Science 282: 1145-1147.

TROUNSON A, LEETON J, BESANKO M, WOOD C, CONTI A (1983). Pregnancy established in an infertile patient after transfer of a donated embryo fertilised in vitro. Brit Med J 286: 835-838.

TROUNSON A, LEETON J F, WOOD C, WEBB J, WOOD J (1981). Pregnancies in humans by fertilization in vitro and embryo transfer in the controlled ovulatory cycle. Science 212: 681.

TROUNSON A, MOHR L (1983). Human pregnancy following cryopreservation, thawing and transfer of an eight-cell embryo. Nature 305: 707-709.

VAN BLERKOM J, OMBELET W, KLERKX E, JANSSEN M, DHONT N, NARGUND G, CAMPO R (2014). First births with a simplifiedculture system for clinical IVF and embryo transfer. Reprod BioMed Online 28: 310-320.

VAN STEIRTEGHEM A C, NAGY Z, JORIS H, LIU J, STAESSEN C, SMITZ J, WISANTO A, DEVROEY P (1993). High fertilization and implantation rates after intracytoplasmic sperm injection. Hum Reprod 8: 1061-1066.

VERLINSKY Y, RECHITSKY S, CIESLAK J, IVAKHNENKO V, WOLF G, LIFCHEZA, KAPLAN B, MOISE J, WALLE J, WHITE M, GINSBERG N, STROM C, KULIEV $A$ (1997). Preimplantation diagnosis of single gene disorders by two-step oocyte genetic analysis using first and second polar body. Biochem Mol Med 62: 182-187.

VERLINSKY Y, RECHITSKY S, SCHOOLCRAFT W, STROM C, KULIEV A. (2001) Preimplantation diagnosis for Fanconi anemia combined with HLA matching. JAMA 285, 3130-3133

VERPOEST W, STAESSEN C, BOSSUYT P M, GOOSSENS V, ALTARESCU G BONDUELLE M, DEVESA M, ELDAR-GEVA T, GIANAROLI L, GRIESINGER G, KAKOUROU G, KOKKALI G, LIEBENTHRON J, MAGLI M C, PARRIEGO M, SCHMUTZLER A G, TOBLER M, VAN DER VENK, GERAEDTS J, SERMON K (2018). Preimplantation genetic testing for aneuploidy by microarray analysis of polar bodies in advanced maternal age: a randomized clinical trial. Hum Reprod 33: 1767-1776.

WALLER L (1990). Consolidated reports of the Victorian injuiry into IVF and related issues. Committee to consider the social, ethical and legal issues arising from in-vitro fertilization ( $2^{\text {nd }}$ reprint), Melbourne, Victoria,

WALLER L. (1992). Australia: the law and infertility -the Victorian experience. In Law reform and human reproduction (Ed. S A M McLean). Dartmouth, London.

WELLS D, SHERLOCK J K, HANDYSIDE A H, DELHANTY J D (1999). Detailed chromosomal and molecular genetic analysis of single cells by whole genome amplification and comparative genomic hybridisation. NucleicAcids Res27:12141218.

WHITTEN W K (1956). Culture of tubal mouse ova. Nature 177: 96. WHITTEN W K (1957). Culture of tubal ova. Nature 179: 1081-1082. WHITTINGHAM D G (1968). Fertilization of mouse eggs in vitro. Nature 220: 592-593.

WIKLAND M, ENK L, HAMBERGER L (1985). Transvesical and transvaginal approaches for the aspiration of follicles by use of ultrasound. Annals NY Acad Sci 442: 182-194.

WILTON L (2018). The development of preimplantation genetic diagnosis for mono- 
genic disease and chromosome imbalance. In In-Vitro Fertilization; The Pioneers History (Eds. G Kovacs, P Brinsden, A deCherney). CUP, Cambridge. pp.180-191.

WOOD C, WESTMORE A (1984). Test tube conception. George Allen and Unwin, London.

YANAGIMACHI R, CHANG M C (1963). Fertilization of hamster eggs in vitro. Nature 200: $281-282$.

YANAGIMACHI R, CHANG M C (1964). In vitro fertllization of golden hamster eggs.
J Exp Zool 156: 361-375.

YANG W H (1963). The nature of human follicular ova and fertilization in vitro. J Jpn Obstet Gynecol Soc 15: 121-130.

ZHANG J, LIU H, LUO S, LU Z, CHÁVEZ-BADIOLA A, LIU Z, YANG M, MERHI Z, SILBER S J, MUNNÉ S, KONSTANTINIDIS M, WELLS D, TANG J J, HUANG T (2017). Live birth derived from oocyte spindle transfer to prevent mitochondrial disease. Reprod BioMed Online 34: 361-368. 


\section{Further Related Reading, published previously in the Int. J. Dev. Biol.}

Differential regulation of cumulus cell transcription during oocyte maturation in vivo and in vitro

Giovanni Coticchio, Libby Ophir, Yuval Yung, Micha Baum, Mariabeatrice Dal Canto, Mario Mignini-Renzini, Fausta Brambillasca, Rubens Fadini and Ariel Hourvitz

Int. J. Dev. Biol. (2017) 61: 433-437

https://doi.org/10.1387/ijdb.160364gc

Insulin-like growth factor 1 acts as an autocrine factor to improve early embryogenesis in vitro

Charmaine J. Green and Margot L. Day

Int. J. Dev. Biol. (2013) 57: 837-844

https://doi.org/10.1387/ijdb.130044md

Triploidy - the breakdown of monogamy between sperm and egg

Hey-Joo Kang and Zev Rosenwaks

Int. J. Dev. Biol. (2008) 52: 449-454

https://doi.org/10.1387/ijdb.082602hk

Enhanced development of porcine embryos cloned from bone marrow mesenchymal stem cells Hai-Feng Jin, B. Mohana Kumar, Jung-Gon Kim, Hye-Jin Song, Yeon-Ji Jeong, Seong-Keun Cho, Sivasankaran Balasubramanian, Sang-Yong Choe and Gyu-Jin Rho

Int. J. Dev. Biol. (2007) 51: 85-90

https://doi.org/10.1387/ijdb.062165hj

Anne McLaren--a tribute from her research students

A G Clarke

Int. J. Dev. Biol. (2001) 45: 491-495

http://www.intjdevbiol.com/web/paper/11417890

A history of mammalian embryological research

H Alexandre

Int. J. Dev. Biol. (2001) 45: 457-467

http://www.intjdevbiol.com/web/paper/11417885

Review of scientific contributions by the Belgian medical centers concerned with human in vitro fertilization and embryo transfer (IVF)

$Y$ Englert and $\mathrm{M}$ Van den Bergh

Int. J. Dev. Biol. (1992) 36: 197-204

http://www.intjdevbiol.com/web/paper/1627470
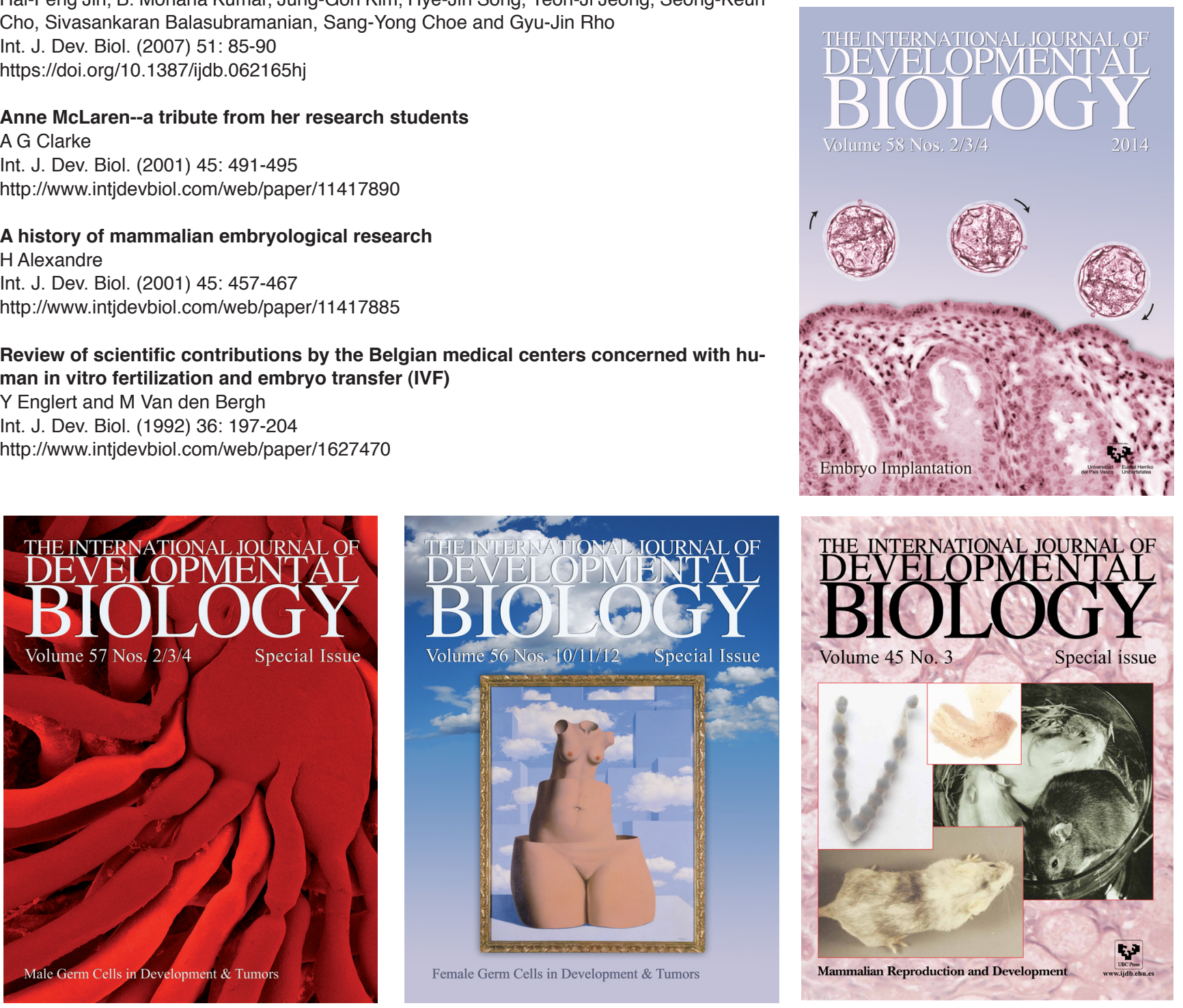